\title{
Note on Orthography
}

Throughout the book I have preferred modern Turkish orthography ("Bayezit" rather than "Bayezid") and the avoidance of diacritics except when necessary; thus, for example, reaya rather than re'aya. When using words of Arabic origin I use the Turkish rather than the Arabic spelling, so medrese, not madrasa. Greek words have been transliterated according to the ELOT system. The only exception to that is the names of Greek authors who have published in English and have not followed ELOT. Their names appear as published. For simplicity's sake I have used modern place names, so "Plovdiv" rather than "Philippoupolis." The only exception is the vexed question of Constantinople/Istanbul. When referring to the Byzantine period I have used "Constantinople," otherwise it is "Istanbul." 